\title{
Erratum: Genetic link between renal birth defects and congenital heart disease
}

Jovenal T. San Agustin, Nikolai Klena, Kristi Granath, Ashok Panigrahy, Eileen Stewart, William Devine, Lara Strittmatter, Julie A. Jonassen, Xiaoqin Liu, Cecilia W. Lo \& Gregory J. Pazour

Nature Communications 7:11103 doi: 10.1038/ncomms11103 (2016); Published 22 Mar 2016; Updated 8 Jun 2016

In Fig. 6 of this Article, defects in the tectonic complex were inadvertently labelled during the production process as causing postnatal, rather than prenatal cysts. The correct version of the figure appears below.

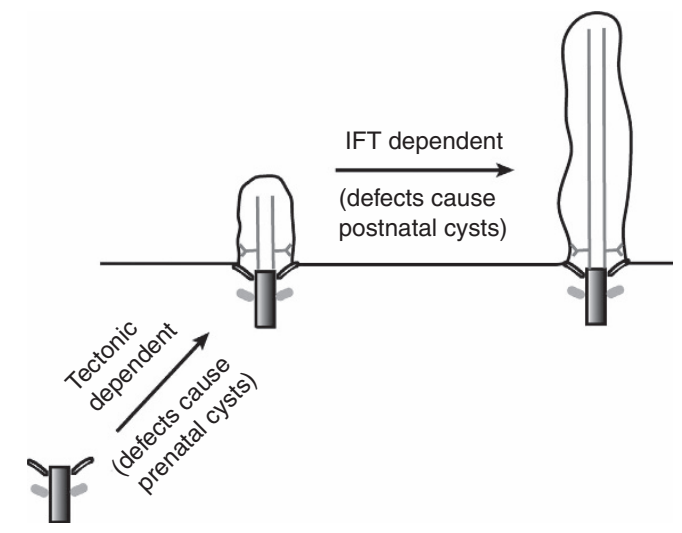

Figure 6

(c) (i) This work is licensed under a Creative Commons Attribution 4.0 International License. The images or other third party material in this article are included in the article's Creative Commons license, unless indicated otherwise in the credit line; if the material is not included under the Creative Commons license, users will need to obtain permission from the license holder to reproduce the material. To view a copy of this license, visit http://creativecommons.org/licenses/by/4.0/ 